\title{
The Heterogeneity of Village Cadres and Poverty Reduction Zang Dungang ${ }^{1, a}$ Luo Yuke, b
}

\author{
${ }^{1}$ School of economics, Sichuan Agricultural University, Chengdu, Sichuan, China \\ ${ }^{2}$ School of economics, Sichuan Agricultural University, Chengdu, Sichuan, China \\ azangdungang@163.com, b405548241@qq.com
}

Keywords: village cadres; heterogeneity; poverty reduction

\begin{abstract}
By using the data of 7 provinces, 757 administrative villages and 31615 famers in the minority regions of the Midwest, this paper investigates the relationships between Village cadres heterogeneity and poverty reduction. And we find that the age of the village cadres, ethnic identity, investment promotion, income and the education background have a significant positive impact on farmer poverty reduction. Using the village collective financial income as the instrumental variable, we find that Village cadres of every $1 \%$ increase in wage income, the poverty rate will be reduced by $0.007 \%$, Therefore, we table four proposals, including that the choice of the village and village officer should follow the principle of "young and old ", encouraging to choose village cadres of ethnic minorities, encouraging investment promotion and investment stay in the village, setting within a reasonable range of income of village cadres. The conclusions above mean that it is of great political significance to solve the problem of poverty reduction of the heterogeneity of village cadres.
\end{abstract}

\section{Introduction}

The Chinese party and government have been paying close attention to poverty alleviation work, and poverty alleviation has been at the core. To ensure that farmers are lifted out of poverty, the government should raise the spirits of the masses of cadres in the poverty-stricken areas and resolutely change the confidence and determination of poverty and backwardness. Do precisely lies in grassroots governance for poverty alleviation, and public officials such as village cadres and party members and cadres responsibility is clear and know whether or not in place, whether solid style, methods properly, to a certain extent determines the effect of poverty reduction, affects the image of the government. Therefore, the impact of the heterogeneity of village cadres on poverty reduction is of great practical significance to the current 70 million poor people. The existing literature rarely deals with the influence of the heterogeneity of village cadres on poverty reduction. Therefore, from the theoretical perspective, studying the heterogeneity of village cadres also has theoretical significance for the impact of poverty reduction. The main contribution of this paper is to use the central university for nationalities in 2012 school of economics and the Chinese academy of social sciences institute of ethnology and anthropology research data, in view of the poor areas the Midwest 7 provinces, empirical research on the effects of heterogeneity research on poverty reduction effect of village cadres, and from the two aspects of the farmers' income and the income gap analysis on various aspects of village cadres quality influence on rural economic development.

\section{Literature review and hypothesis}

Arnim Scheidel (2014) believes that the poverty problem mainly comes from the shortage of land resources. Farmers need to make a diversified livelihood and make new economic activities to achieve poverty reduction. Swati Dutta (2015) tested that malnutrition in most places would affect the accumulation of farmers' assets, while the impact of illiteracy was uneven. In the study of India, Deaton\& Dreze (2002) believed that factors such as health and education could have an impact on 
poverty. Cheng, Jin Yanhong and others (2014) also believe that the human capital represented by health and education will affect the income level of farmers and have an impact on rural poverty alleviation. Chen qi (2012) believes that human capital investment will have a greater impact on poverty reduction. While investigating the causes of poverty, Armando Barrientos (2010) found that the majority of respondents believed that poverty would be long-lasting and pessimistic about breaking out of poverty. MICHELLE s. MOOD (2005) believed that the economic goals and election of village cadres influenced the development of villages, and the ability of village cadres to be leaders led economic growth. On the basis of the above literature, we carried out the following research with questions. Based on the definition of village cadres' heterogeneity and poverty reduction, we make several assumptions: Hypothesis 1: the time of the village cadres and the age of the village cadres are positively correlated with the farmers' poverty reduction. Hypothesis 2: the education of village cadres and the presence of village cadres are positively correlated with the reduction of poverty reduction. Hypothesis 3: village cadres are positively correlated with poverty reduction among ethnic minorities and farmers. Hypothesis 4: the income standard of village cadres is positively correlated with the poverty reduction.

\section{Data and methodology}

The data was being investigated by central university for nationalities school of economics and the Chinese academy of social sciences institute of ethnology and anthropology. This study based on primary data collected from 757 village leader spreading over 757 villages belonging to 7 provinces. such as the Inner Mongolia autonomous region, Ning Xia hui autonomous region, Qing Hai province, Xin Jiang uygur autonomous region, Guang Xi Zhuang autonomous region, Gui Zhou province, Hu Nan province. Though the study area is located in the poor rural areas, the results can be generalized across to the whole country. Rural survey gathers administrative villages population employment and economic, agriculture and village collective land, finance and management, public service aspects of the micro information, fully reflects the basic situation of the Midwest rural economy.

Model setting: probit regression model: The model is establishing in this section to prove the relationship between the heterogeneity of village leaders and the investment of farmland irrigation facilities. Specific as follows:

$p_{i}=$ irrigation facilities $_{i}=\beta_{0}+\beta_{1} x_{1}+\beta_{2} x_{2}+\beta_{3} x_{3}+\beta_{4} x_{4}+\beta_{5} x_{5}+\sum_{z=1}^{21} B_{i} x_{z i}+\mu_{i}$

In the model (1), the explanatory variable whether povertyi represents the first person to be out of poverty, 1 represents poverty reduction, and 0 representatives have not yet reduced poverty. The 15 control variables involved in the four aspects of farmers' individual characteristics, social environment, natural environment and public service are included. This paper makes a certain arrangement of data variables, and the descriptive statistics of all variables form table 1.

Table 1 Descriptive statistics of variables

\begin{tabular}{lccc}
\hline \multicolumn{1}{c}{ Variable } & Variable definitions & $\begin{array}{c}\text { average } \\
\text { value }\end{array}$ & $\begin{array}{c}\text { standard } \\
\text { deviation }\end{array}$ \\
\hline income1 & The farmers' 2011 net income & 4336.633 & 2169.076 \\
& Whether farmers are out of poverty & & \\
whether poverty & & 0.1120112 & 0.3153854 \\
time & From which year began to act as village cadre & 2004.292 & 9.376653 \\
age1 & The age of the village cadre in 2011 & 47.316475 & 7.717646
\end{tabular}




\begin{tabular}{|c|c|c|c|}
\hline $\begin{array}{l}\text { education } \\
\text { background }\end{array}$ & $\begin{array}{c}\text { high school, } 4=\text { high school, technical school, } 5= \\
\text { secondary school, } 6=\text { college, } 7=\text { university degree } \\
\text { and above; }\end{array}$ & 2.844623 & 1.361544 \\
\hline nationality & The ethnic minority of village cadres $=1$, han $=0$; & 0.6344412 & 0.4815954 \\
\hline earning & The annual income of the village cadres in 2011 & 6298.603 & 752.0976 \\
\hline $\begin{array}{l}\text { invite } \\
\text { investment }\end{array}$ & $\begin{array}{l}\text { Whether the village cadre has the attractors project } \\
\text { to the village. }\end{array}$ & 0.0631938 & 0.2433156 \\
\hline age 2 & The age of the farmer & 33.91623 & 19.79277 \\
\hline gender & Men $=1$, women $=0$ & 0.4776596 & 0.4995086 \\
\hline $\begin{array}{l}\text { household } \\
\text { Category }\end{array}$ & $\begin{array}{l}\text { It refers to the state of the peasants. Individual } \\
\text { business and cadre households }=3 \text {, common }=2 \text {, }\end{array}$ & 2.090543 & 0.2907237 \\
\hline $\begin{array}{l}\text { cooperative } \\
\text { economic }\end{array}$ & $\begin{array}{c}\text { The cooperative economic organizations that farmers } \\
\text { voluntarily participate in. Participation }=1, \text { not } \\
\text { participating }=0\end{array}$ & 0.0226744 & 0.1488655 \\
\hline outside & $\begin{array}{l}\text { Whether or not farmers are going out for } \\
\text { employment is equal to } 1 \text {, or not equal to } 0 \text {; }\end{array}$ & 0.1286727 & 0.3348487 \\
\hline $\begin{array}{l}\text { medical } \\
\text { treatment }\end{array}$ & $\begin{array}{c}\text { The medical mutual aid system that the farmer } \\
\text { volunteers to participate in, participation }=1, \text { not } \\
\text { participating }=0 ;\end{array}$ & 0.987681 & 0.1103068 \\
\hline $\begin{array}{l}\text { county level } \\
\text { cadre }\end{array}$ & $\begin{array}{l}\text { If there are any cadres at the county level or above in } \\
\text { the party and government departments at the county } \\
\text { level and above, yes }=1, \text { no }^{\prime}=0\end{array}$ & 0.5639988 & 0.4958952 \\
\hline old areas & $\begin{array}{l}\text { The village is a revolutionary old area. Is equal to } 1 \text {, } \\
\qquad \text { or not equal to } 0\end{array}$ & 0.1714249 & 0.3768859 \\
\hline ghettoize & Is the village a minority area? yes $=1 ; \mathrm{No}=0$ & 0.7146605 & 0.4515832 \\
\hline endemic & Is this village an endemic area? yes $=1 ; \mathrm{No}=0$ & 0.0290694 & 0.1680038 \\
\hline distance & $\begin{array}{l}\text { The village is about the distance from the nearest } \\
\text { county }\end{array}$ & 31.64783 & 25.09245 \\
\hline terrain & Mountain $=3$, hilly $=2$, plain $=1$ & 2.380824 & 0.8300797 \\
\hline disaster & $\begin{array}{l}\text { Whether there is a natural disaster affecting the } \\
\text { production and living of farmers in this village. Is }= \\
\qquad 1 ; \mathrm{N}=0 ;\end{array}$ & 0.5656919 & 0.4956737 \\
\hline concede land & $\begin{array}{l}\text { It refers to the situation of reducing the area of } \\
\text { cultivated land due to the implementation of the } \\
\text { conversion of farmland to forestry. }\end{array}$ & 0.6965101 & 0.4597725 \\
\hline public program & $\begin{array}{l}\text { The fund originates from the superior or external } \\
\text { level, affecting the economic life of the village } \\
\text { project. }\end{array}$ & 0.1793333 & 0.3836389 \\
\hline
\end{tabular}

\section{Results and Analysis}

The measurement software used in this paper is stata13, and before verifying the results, the correlation between all variables is tested to prove that there is no correlation between all variables. The correlation coefficient between all variables is under 0.5 , which satisfies the criteria of the regression. After a collinear test, it is proved that there are no multiple collinear problems between the 
models, so this paper argues that the regression results of the model are more accurate and reliable. Table 2 main report the heterogeneity of the village cadres regression results on poverty reduction, of which the first (1), (3) column is in poverty reduction/various poverty), village cadres as time (year), age (age1), education (education) and income (earning), investment promotion and capital introduction (invite) and national (nationality), not the introduction of control variable Probit and OLS regression results. The results show that the age and investment attraction of village cadres have a significant positive impact on farmers' poverty reduction, and are significant at the $1 \%$ level. The income and ethnic groups of village cadres have a positive impact on the poverty reduction of farmers, and are significant at the $1 \%$ level of the Probit model, which is significant at the $5 \%$ level of OLS model. The education of village cadres has a positive impact on poverty reduction, which is significant at the $10 \%$ level. The (2) and (4) columns are the analytical results after the regression of Probit and OLS with all four class control variables. The results showed that the age of the village cadres to villagers poverty reduction coefficient is 0.02 , the influence of the symbol is positive, and the $1 \%$ significance level, prove that the age of village cadres has a positive promoting effects on the farmers' poverty reduction, prove the hypothesis of a set. The influence of the village cadres education on poverty reduction coefficient is 0.05 , the symbol is positive, and the $10 \%$ significance level, and whether the village cadres to carry on the investment promotion and capital introduction on poverty reduction coefficient is 0.39 , the influence of the symbol is positive, at $5 \%$ significant level, education and investment promotion and capital introduction of village cadres in the farmers' poverty reduction has a positive role in promoting, prove the hypothesis 2 set is correct. The influence of village cadres on poverty reduction is 0.3 , the symbol is positive, and in the Porbit model, it is significant at the $1 \%$ level. In the OLS model, it is significant at 5\% level. It shows that the minority attributes of village cadres can have a positive impact on poverty reduction, and proves the inference of hypothesis 3 . The influence coefficient of village cadres' income on poverty reduction is 0.0003 and the symbol is positive. It's significant at the $10 \%$ level. It shows that the income of village cadres has a positive impact on poverty reduction, which is consistent with hypothesis 4 .

Table 2 The empirical results

\begin{tabular}{|c|c|c|c|c|}
\hline \multirow[t]{2}{*}{ Variables } & \multicolumn{4}{|c|}{ Dependent Variable: whether poverty } \\
\hline & (1) & (2) & (1) & (2) \\
\hline Variables & Probit & Probit & OLS & OLS \\
\hline \multirow[t]{2}{*}{ earning } & $0.0005 * * *$ & $0.0003^{*}$ & $0.0357 * *$ & $0.0389 *$ \\
\hline & $(0.0000)$ & $(0.0002)$ & $(0.0003)$ & $(0.0003)$ \\
\hline \multirow[t]{2}{*}{ age1 } & $0.0238 * * *$ & $0.0213 * * *$ & $\begin{array}{c}0.0075^{* *} \\
*\end{array}$ & $0.0066^{* * *}$ \\
\hline & $(0.0018)$ & $(0.0035)$ & $(0.0084)$ & $(0.0051)$ \\
\hline \multirow[t]{2}{*}{ education } & $0.0547 *$ & $0.0533^{*}$ & $0.2353 *$ & $0.2084^{*}$ \\
\hline & $(0.0101)$ & $(0.0276)$ & $(0.0531)$ & $(0.1244)$ \\
\hline \multirow[t]{2}{*}{ Year } & 0.023 & 0.0219 & 0.0012 & 0.0009 \\
\hline & $(0.0012)$ & $(0.0035)$ & $(0.0022)$ & $(0.0829)$ \\
\hline \multirow[t]{2}{*}{ invite } & $0.351 * * *$ & $0.3854 * *$ & $\begin{array}{c}0.8792 * * \\
*\end{array}$ & $0.8425^{* *}$ \\
\hline & $(0.0542)$ & $(0.1514)$ & $(0.0982)$ & $(0.0252)$ \\
\hline nationality & $0.3328 * * *$ & $0.3569^{* * *}$ & $0.5779 * *$ & $0.6002 * *$ \\
\hline
\end{tabular}


Note: $* * *, * *, *$ respectively indicates the significance of parameters at the level of $1 \%, 5 \%$, and $10 \%$. The values in parentheses are the robust standard deviations. It remains the same in the following table.

\section{Implications}

According to the conclusions of this paper, the following policy recommendations for poverty reduction are as follows: (a) Village cadres should attach great importance to the culture of their own quality, and strive to improve the level of record of formal schooling education, become the high quality human capital, should also actively learn the experience of senior, knowledge and experience will have the biggest effect. (b)The government should encourage to break on the village of village cadres election ethnic discrimination, properly enlarge the proportion of ethnic minority cadres, not only to a certain extent, to get more policy support, combined with the feelings of the relationship among nationalities, ethnic minorities and honest will eliminate some of rent-seeking behavior of village cadres, to reduce incidents of infringement to the interests of farmers.(c) The village cadres should according to the strategic development plan of the village, actively draw up the plan and encourage the enterprises to invest in the factory. On the premise of not affecting the ecological environment of the village, the economic development of the villages and the employment proportion of the villages will be improved, so as to realize the harmonious coexistence between man and nature and economy. (d) At the economic level of its village, the income level of village cadres is reasonably set. It is necessary to avoid the problem that the low income of village cadres can cause the lack of enthusiasm of the village cadres, and also avoid the harm of the rent-seeking behavior of the village cadres to the economic income of the peasants.

\section{References}

[1] Arnim Scheidel, 2014. Land poverty and emerging ruralities in Cambodia: insights from Kampot province [J].Environment, Development and Sustainability: 823-840p.

[2] Swati, 2015. Identifying Single or Multiple Poverty Trap: An Application to Indian Household Panel Data[J]. Social Indicators Research: 157-179p.

[3] Deaton\&Dreze, 2002. Income and Expenditure Switching Among the Impoverished During Structural Adjustment in India. Economics of Planning: 221-252p.

[4] Cheng, 2014. Rural poverty reduction: it should pay more attention to education or health empirical evidence based on income growth and gap narrowing. Economic research: 130-144P.

[5] Chen qi, 2012. Human capital and income poverty of rural households in contiguous areas. Jiangxi social science:231-235p.

[6] Armando Barrientos, 2011. Attitudes to Chronic Poverty in the Global village . Social Indicators Research: 101-114p.

[7] MICHELLE S. MOOD, 2005. Opportunists, predators and rogues: the role of local state relations in shaping Chinese rural development. Journal of Agrarian Change: 217-250p. 